\title{
Effect of Deltamethrin on Haematological Indices of Common Carp (Cyprinus carpio L.)
}

\author{
Z. SVOBODOVÁ ${ }^{1,3}$, V. LUSKOVÁ ${ }^{2}$, J. DRASTICHOVÁ ${ }^{1}$, M. SVOBODA ${ }^{1}$, V. ŽLÁBEK ${ }^{3}$ \\ ${ }^{1}$ University of Veterinary and Pharmaceutical Sciences Brno, Czech Republic \\ ${ }^{2}$ Institute of Vertebrate Biology, AV CR, Brno, Czech Republic \\ ${ }^{3}$ University of South Bohemia, Research Institute of Fish Culture and Hydrobiology, Vodňany, Czech Republic
}

Received June 6, 2002

Accepted March 25, 2003

Abstract

Svobodová Z., V. Lusková, J. Drastichová, M. Svoboda, V. Žlábek: Effect of Deltamethrin on Haematological Indices of Common Carp (Cyprinus carpio L.). Acta Vet. Brno 2003, 72: 79-85.

The aim of this study was to assess the effect of deltamethrin [(S)- a -cyano-3-phenoxybenzyl (1R,3R)-3-(2,2-dibromvinyl)-2,2-dimethylcyclo-propancarboxylate] on common carp (Cyprinus carpio $\mathrm{L}$.). The effect was assessed on the basis of the results of acute toxicity tests and on the comparison of results of haematological examination of a control and an experimental group exposed to Decis flow 2.5 pesticide preparation (active substance $25 \mathrm{~g} . \mathrm{l}^{-1}$ of deltamethrin). The acute semistatical toxicity test lasting $96 \mathrm{~h}$ was performed on common carp juveniles. The 96hLC50 value of Decis flow 2.5 was $0.058 \mathrm{mg} . \mathrm{l}^{-1}$. Examination of erythrocyte and leukocyte profile was performed on 15 control and 28 experimental specimens of one-to-two-year-old common carp after $96 \mathrm{~h}$ of exposure to Decis flow 2.5 in a concentration of $0.13 \mathrm{mg} . \mathrm{l}^{-1}$. The experimental group showed significantly lower values $(p<0.01)$ of erythrocyte count $(\mathrm{RBC})$, haemoglobin content $(\mathrm{Hb})$, haematocrit $(\mathrm{PCV})$ and plasma total protein $(\mathrm{TP})$ compared to the control group. Values of $\mathrm{MCV}, \mathrm{MCH}$ and $\mathrm{MCHC}$ were comparable in the two groups during the study. Also, the leukocyte count (Leuko) and relative and absolute count of lymphocytes, monocytes, neutrophil granulocytes and their developmental forms were comparable in the two groups. The deltamethrin-based Decis flow 2.5 pesticide preparation was classified among substances strongly toxic for fish. Changes in the erythrocyte profile and plasma total protein after exposure to deltamethrin-based preparation may be referred to possible disruption of haematopoiesis and proteosynthesis.

Pyrethroids, acute toxicity, erythrocyte profile, leukocyte profile, total protein

In the past 10-15 years the application of pyrethroids as insecticide and antiparasitary preparations has very markedly increased. Thus, pyrethroids are successively replacing organophosphate pesticides. The main advantage of pyrethroids is their photostability, high effectiveness already in low concentrations, easy disintegration and low toxicity to birds and mammals (Bradbury and Coast 1989a; Maud et al. 1998; Gangolli et al. 1999). Fish are extremely susceptible to these substances. The 96hLC50 value, determined in laboratory tests, generally lies below $10 \mu \mathrm{g} \cdot \mathrm{l}^{-1}$ (Bradbury and Coast $1989 \mathrm{~b}$ ).

However, the situation under natural conditions is considerably different from artificially controlled constant conditions in the course of laboratory tests. An important factor is the rapid absorption of the pyrethroid by plants, sediments and organic material, markedly decreasing their accessibility and thus also the risk for aquatic organisms. Natural studies have demonstrated that the negative effect of pyrethroids on fish under natural conditions is improbable, provided that all safety measures indicated by the producer are maintained (Hill et al. 1994; Maud et al. 1998). However, it is quite real if they are not maintained, as shown by the case of fish mortality in Lake Balaton in 1995, caused by fish poisoning with a deltamethrin-based preparation (Nemcsok et al. 1999).

Address for correspondence:

Prof. MVDr. Zdeňka Svobodová, DrSc

University of Veterinary and Pharmaceutical Sciences

22 Brno
Phone: +420541562565

Fax: +4205492430 20

http://www vfu.cz/acta-vet/actavet.htm 
In fish cultures, pyrethroids are applied to control some parasitic diseases caused by, e.g., Lepeophtherius salmonis in farm cultures of salmonids (Braidwood and Hart 1998; Toovey and Lyndon 2000; Roth 2000; Martinsen et al. 2001; Sevatdal and Horsberg 2001).

Deltamethrin is a widely used pesticide based on pyrethroids. It is among the most effective pyrethroid preparations (Bradbury and Coats 1989b). The mechanism of its effectiveness in the case of fishes is the same as that of other pyrethroids containing -cyano3 -phenoxybenzyl groups. They block the sodium channels of nerve filaments, thereby lengthening their depolarisation phase; moreover, they affect the GABA receptors in the nerve filaments (Hayes 1994; Bradbury and Coats 1989ab). The acute toxicity of deltamethrin is different for different fish species (Haug and Hofman 1990, Golow and Godzi 1994; Srivastava et al. 1997), varying between 0.5 and $1.8 \mu \mathrm{g} . \mathrm{l}^{-1}$ (Gangolli et al. 1999). No data on haematological changes in fish caused by deltamethrin have been found in the available literature.

The assessment of the ecotoxicological risks caused by pesticides to ecosystems are based on data on the toxicity and effects of pesticide preparations to non-target organisms. Fish are among the group of non-target aquatic organisms. The present paper is a contribution to the assessment of toxicity and effects of a deltamethrin-based pesticide to fish.

\section{Materials and Methods}

The goal was to assess the effect of deltamethrin [(S)- a-cyano-3-phenoxybenzyl (1R,3R)-3-(2,2-dibromvinyl)2,2 -dimethylcyclo-propancarboxylate] on fish. It was tested in the form of Decis flow 2.5 pesticide, the active substance of which is deltamethrin in the amount of $25 \mathrm{~g} \cdot \mathrm{l}^{-1}$. The toxic effect was assessed by the results of acute toxicity tests and results of haematological examination of common carp after exposure to this pesticide.

The acute toxicity test on common carp with Decis flow 2.5 followed the OECD Direction No. 203 and Methodical Manual ISO 7346/2. Juveniles of common carp (Cyprinus carpio L.) $9.9 \pm 1.19 \mathrm{~g}$ in mean body weight and 72.6 $\pm 3.61 \mathrm{~mm}$ mean body length were used for the test. Seven various concentrations and a control were used in the basic test. Ten fish specimens were used for every concentration and also in the control. The test was performed semistatically for $96 \mathrm{~h}$. The bath was changed every $24 \mathrm{~h}$. Basic physical and chemical indices of diluting water used in the acute toxicity test were as follows: $\mathrm{pH} 7.80 ; \mathrm{ANC}_{45}$ (alkalinity) $1.05 \mathrm{mmol}^{-1} \mathrm{I}^{-1} \mathrm{BNC}_{83}$ (acidity) $0.03 \mathrm{mmol}^{-1} \mathrm{I}^{-1}$ $\mathrm{COD}_{\mathrm{Mn}} 1.0 \mathrm{mg} . \mathrm{l}^{-1} ; \mathrm{NH}_{4}{ }^{+}+\mathrm{NH}_{3} 0.1 \mathrm{mg} . \mathrm{l}^{-1} ; \mathrm{NO}_{3}^{-} 11.6 \mathrm{mg} .1^{-1} ; \mathrm{NO}_{2}^{-} 0.015 \mathrm{mg} . .^{-1} ; \mathrm{PO}_{4}^{3-} 0.01 \mathrm{mg} .1^{-1} ;$ sum of $\mathrm{Ca}+\mathrm{Mg}$ $14 \mathrm{mg} \cdot \mathrm{l}^{-1}$. Water temperatures in the test ranged from 19 to $21^{\circ} \mathrm{C}$, oxygen saturation of water ranged between 70 and $100 \%$. The LC50 and LC5 values in the respective time intervals were determined by probit analysis.

Haematological examination of one-to-two-year-old common carp (Cyprinus carpio L.) was performed at the end of $96 \mathrm{~h}$ acute toxicity test with Decis flow 2.5 in concentration of $0.13 \mathrm{mg} \cdot \mathrm{l}^{-1}$. At the same time, the control group of common carp was examined haematologically. The test was performed semistatically with the bath exchanged every $24 \mathrm{~h}$. Diluting water had the same physical and chemical parameters as described above. Water temperatures during the test ranged from 21.0 to $21.8^{\circ} \mathrm{C}$, oxygen saturation of water was above $60 \%$ (ranging from 90 to $110 \%$ ), pH ranged from 7.6 to 7.8. The test was performed in 6 aquaria 2001 in volume. Each aquarium was stocked with 10 specimens of one- to two-year-old common carp ( 2 control aquaria, 4 aquaria with Decis flow 2.5 in concentration $0.13 \mathrm{mg}^{-1}{ }^{-1}$ ).

Examination of erythrocyte and leukocyte profile was carried out on 15 control (body weight $165 \pm 49.8 \mathrm{~g}$ ) and 28 experimental specimens (body weight $183 \pm 42.0 \mathrm{~g}$ ) after $96 \mathrm{~h}$ exposure to concentration of $0.13 \mathrm{mg} .1^{-1}$ Decis flow 2.5 .

Blood was sampled from the caudal vessels and stabilized by $50 \mathrm{IU}$ sodium heparin per $1 \mathrm{ml}$ blood. Erythrocyte count (RBC), haematocrit (PCV), haemoglobin $(\mathrm{Hb})$, mean corpuscular volume (MCV), mean corpuscular haemoglobin $(\mathrm{MCH})$, mean corpuscular haemoglobin concentration (MCHC), leukocyte count (Leuko), differential leukocyte count and plasma total protein were determined in the blood samples (Svobodová et al. 1991). Results were processed statistically by analysis of variance (ANOVA).

\section{Results}

Acute toxicity

The LC50 and LC5 values of Decis flow 2.5 for common carp juveniles in the respective time intervals are given in Fig. 1. The 96hLC50 is the basic value in the acute toxicity test. For common carp juveniles the $96 \mathrm{hLC} 50$ value was $0.058 \mathrm{mg} . \mathrm{l}^{-1}$ of Decis flow 2.5 preparation, which corresponds to $0.00145 \mathrm{mg} . \mathrm{l}^{-1}$ of deltamethrin. 


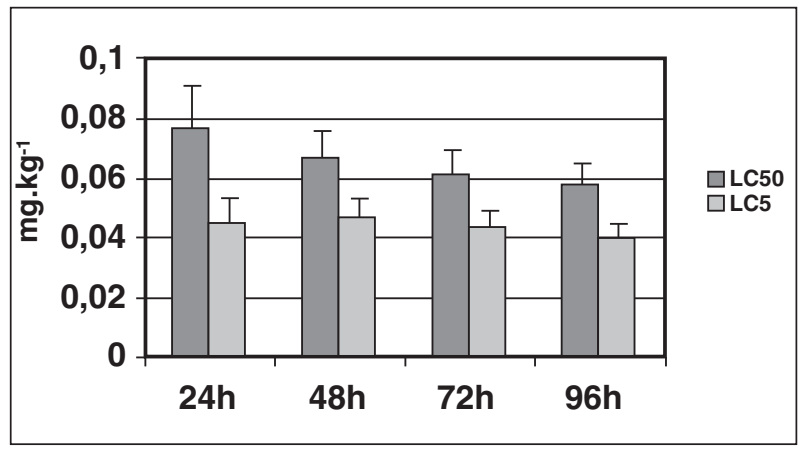

Fig 1. Acute toxicity test of Decis flow 2.5 pesticide in common carp (range means $95 \%$ confidence interval)
In the course of deltamethrin poisoning in carp, the following clinical symptoms were observed: accelerated respiration, loss of movement coordination, fish lay-down at their flank and are moving in this position. Subsequent short excitation stage (convulsions, jumps above the water surface, movement in circles) changes into a resting stage, and an other short-time excitation follows again. In the end, fish fall into damp, move mainly at their flank. Respiration is slowed down, the damp phase and subsequent agony are very long.

Pathoanatomical changes in carp poisoned with deltamethrin were not marked. Compared with control fish, hyperemia and gills turning deep purple were observed.

Haematological profile

Results of erythrocyte profile of the control and experimental common carp under study are given in Fig. 2 and Table 1. Compared to the control specimens, those after the acute

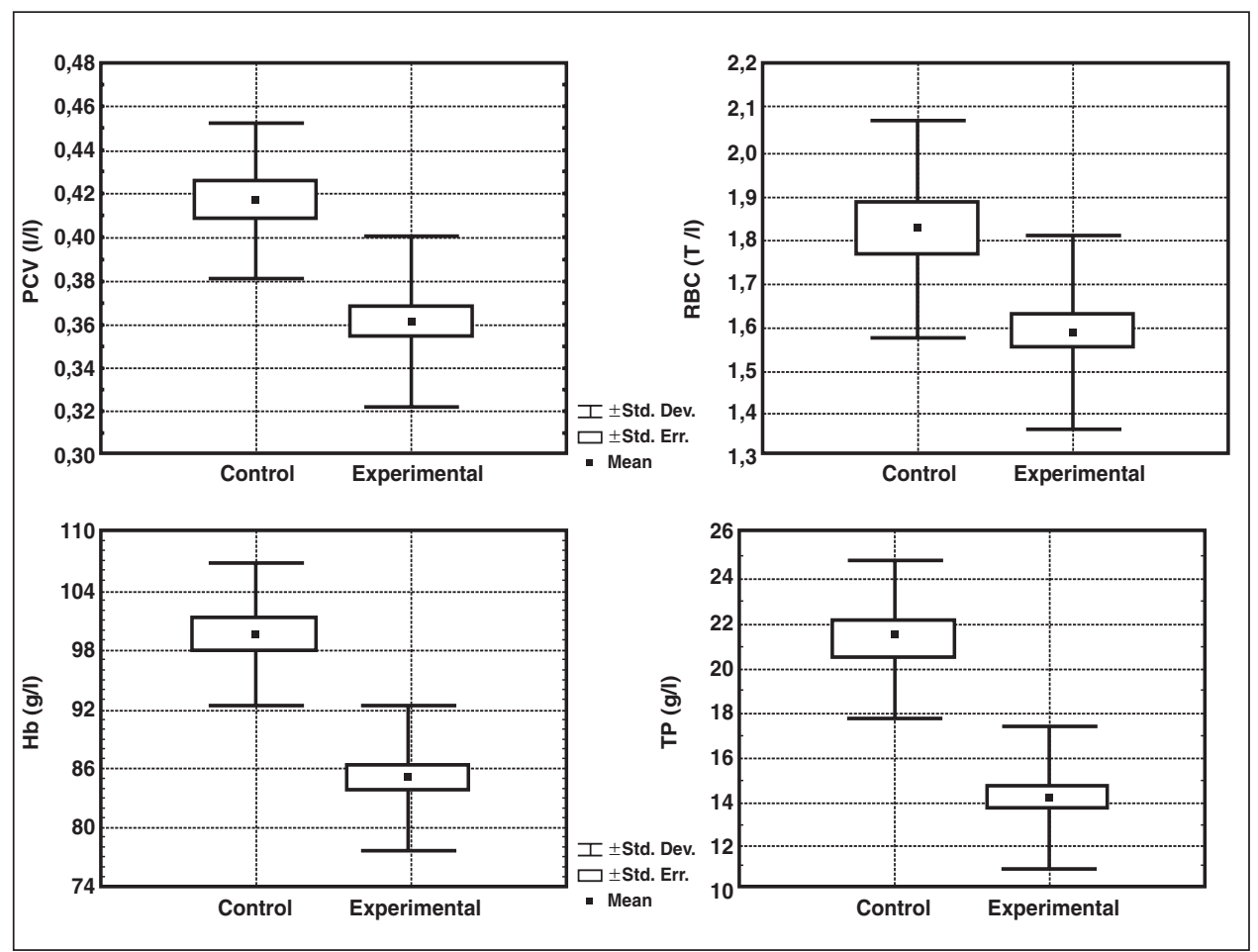

Fig. 2. Haematological indices significantly different in control and experimental groups of common carp affected by acute exposure to Decis flow 2.5 
Table 1

Derived haematological parameters in common carp affected by acute exposure to Decis flow 2.5

\begin{tabular}{|c|c|c|c|c|c|c|c|c|}
\hline Indices & Units & Groups & $\mathrm{N}$ & Mean & S.D. & Variance & $\mathrm{F}$ test & $\begin{array}{c}\text { Probability } \\
(\mathrm{p}<.01)\end{array}$ \\
\hline \multirow{2}{*}{$\mathrm{MCV}$} & \multirow{2}{*}{$\mathrm{fl}$} & control & 15 & 227.87 & 35.76 & 1278.63 & 0.02 & 0.88 \\
\hline & & experiment & 28 & 229.23 & 24.79 & 614.42 & & \\
\hline \multirow{2}{*}{$\mathrm{MCH}$} & \multirow{2}{*}{ pg } & control & 15 & 54.87 & 4.39 & 19.30 & 0.12 & 0.73 \\
\hline & & experiment & 28 & 54.22 & 6.54 & 42.76 & & \\
\hline \multirow{2}{*}{$\mathrm{MCHC}$} & \multirow{2}{*}{$1 / 1$} & control & 15 & 0.24 & 0.02 & 0.00 & 0.51 & 0.48 \\
\hline & & experiment & 28 & 0.24 & 0.02 & 0.00 & & \\
\hline
\end{tabular}

exposure to deltamethrin had significantly lower erythrocyte count $(p<0.01)$, haemoglobin content $(p<0.01)$ and lower haematocrit values $(p<0.01)$. Values recorded for MCV, MCH and $\mathrm{MCHC}$ were comparable in both groups under study.

The results of examinations of the white blood picture of control and experimental carp, $\mathrm{K}_{1-2}$, are given in Fig. 3 and Table 2. Following the acute effect of deltamethrin, the values of total leukocyte count and relative as well as absolute counts of lymphocytes, monocytes, neutrophil granulocytes and their developmental forms were comparable in the control and experimental groups.

A comparison of values of total protein content in the blood plasma of control and experimental carp is given in Fig. 2. The experimental carp exposed to acute effects of the deltamethrin-based pesticide showed a significantly $(p<0.01)$ decreased concentration of total protein in blood plasma.

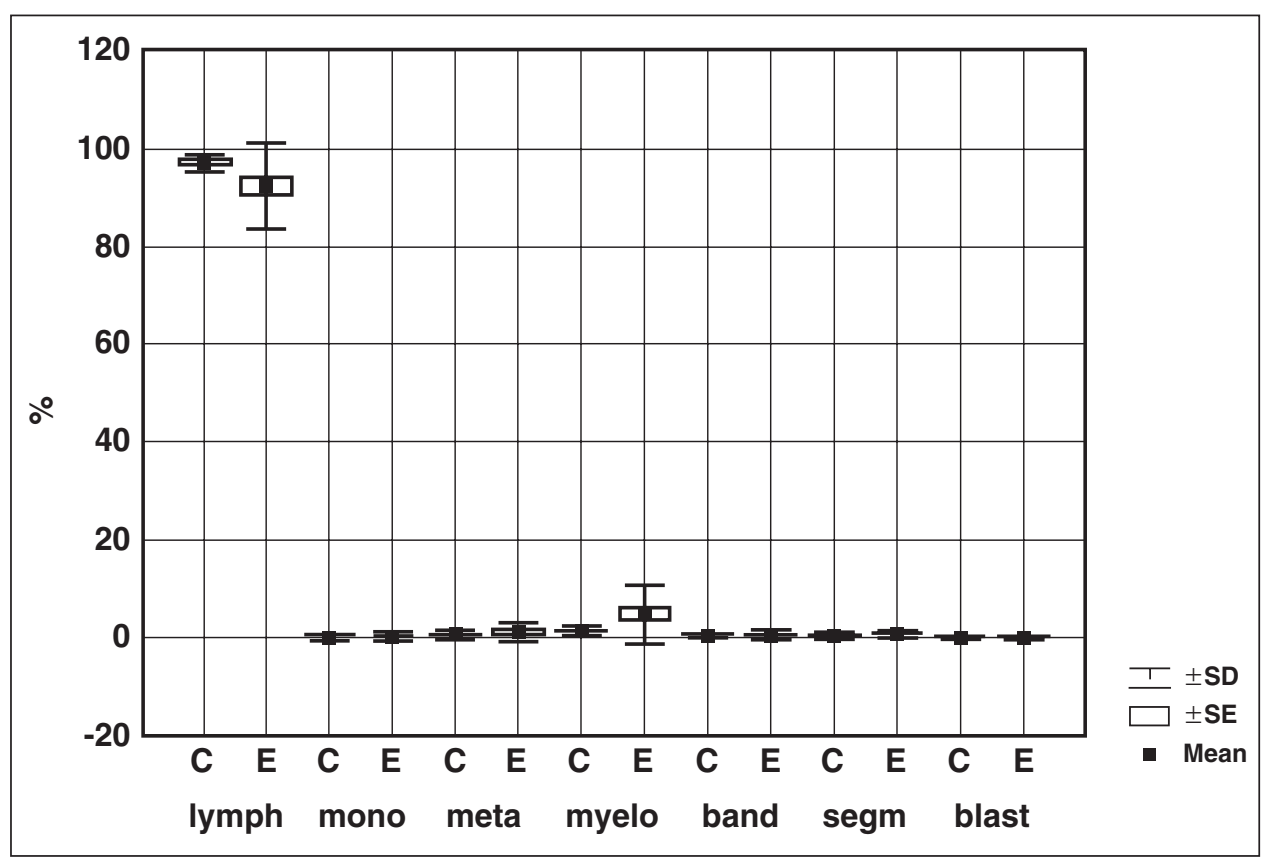

Fig. 3. Leukocyte differential count (\%) in control (C) and experimental (E) groups of common carp affected by acute exposure to Decis flow 2.5 
Table 2

Leukocyte differencial count (G/1) in common carp affected by acute exposure to Decis flow 2.5

\begin{tabular}{|c|c|c|c|c|c|c|c|}
\hline Indices & Groups & $\mathrm{N}$ & Mean & S.D. & Variance & $\mathrm{F}$ test & $\begin{array}{c}\text { Probability } \\
(\mathrm{p}<.05)\end{array}$ \\
\hline Leukocytes & $\begin{array}{c}\text { control } \\
\text { experiment }\end{array}$ & $\begin{array}{l}15 \\
28\end{array}$ & $\begin{array}{l}32.50 \\
34.21\end{array}$ & $\begin{array}{l}4.53 \\
7.87 \\
\end{array}$ & $\begin{array}{l}20.54 \\
61.95\end{array}$ & 0.6 & 0.44 \\
\hline Lymphocytes & $\begin{array}{c}\text { control } \\
\text { experiment }\end{array}$ & $\begin{array}{l}14 \\
28\end{array}$ & $\begin{array}{l}31.58 \\
31.48\end{array}$ & $\begin{array}{l}4.87 \\
7.58\end{array}$ & $\begin{array}{l}23.72 \\
57.42\end{array}$ & 0.002 & 0.96 \\
\hline Monocytes & $\begin{array}{c}\text { control } \\
\text { experiment }\end{array}$ & $\begin{array}{l}14 \\
28\end{array}$ & $\begin{array}{l}0.02 \\
0.14\end{array}$ & $\begin{array}{l}0.05 \\
0.39\end{array}$ & $\begin{array}{l}0.00 \\
0.15\end{array}$ & 1.26 & 0.27 \\
\hline Myelocytes & $\begin{array}{c}\text { control } \\
\text { experiment }\end{array}$ & $\begin{array}{l}14 \\
28\end{array}$ & $\begin{array}{l}0.49 \\
1.72 \\
\end{array}$ & $\begin{array}{l}0.28 \\
2.72 \\
\end{array}$ & $\begin{array}{l}0.08 \\
7.40\end{array}$ & 2.84 & 0.1 \\
\hline Metamyelocytes & $\begin{array}{c}\text { control } \\
\text { experiment }\end{array}$ & $\begin{array}{l}14 \\
28 \\
\end{array}$ & $\begin{array}{l}0.17 \\
0.44 \\
\end{array}$ & $\begin{array}{l}0.25 \\
0.74 \\
\end{array}$ & $\begin{array}{l}0.06 \\
0.55\end{array}$ & 1.73 & 0.2 \\
\hline Band neutrophils & $\begin{array}{c}\text { control } \\
\text { experiment }\end{array}$ & $\begin{array}{l}14 \\
28 \\
\end{array}$ & $\begin{array}{l}0.12 \\
0.16\end{array}$ & $\begin{array}{l}0.17 \\
0.24\end{array}$ & $\begin{array}{l}0.03 \\
0.06 \\
\end{array}$ & 0.22 & 0.64 \\
\hline Segmend neutrophils & $\begin{array}{c}\text { control } \\
\text { experiment }\end{array}$ & $\begin{array}{l}14 \\
28 \\
\end{array}$ & $\begin{array}{l}0.10 \\
0.23\end{array}$ & $\begin{array}{l}0.13 \\
0.26 \\
\end{array}$ & $\begin{array}{l}0.02 \\
0.07\end{array}$ & 3.12 & 0.09 \\
\hline Blasts & $\begin{array}{c}\text { control } \\
\text { experiment }\end{array}$ & $\begin{array}{l}14 \\
28\end{array}$ & $\begin{array}{l}0.00 \\
0.03\end{array}$ & $\begin{array}{l}0.00 \\
0.09\end{array}$ & $\begin{array}{l}0.00 \\
0.01\end{array}$ & 1.67 & 0.2 \\
\hline
\end{tabular}

Discussion

In the course of $96 \mathrm{~h}$ toxicity test of deltamethrin-based pyrethroid preparation Decis flow 2.5 on common carp juveniles, there was no mortality of fish in the control aquarium. Oxygen saturation of water did not drop below $60 \%$ in any concentration tested, nor in the control group. Presence of the substance tested (above $80 \%$ of the nominal concentration) was provided by means of daily exchange of the testing bath. On the basis of the observed value of 96hLC50 $\left(0.058 \mathrm{mg} . \mathrm{l}^{-1}\right)$, the preparation Decis flow $2.5 \mathrm{can}$ be included in the group of substances that are highly toxic for fish: the risk sentence R50 states the values of $96 \mathrm{hLC} 50$ less than $1 \mathrm{mg} . \mathrm{l}^{-1}$. The value of $96 \mathrm{hLC} 50$ for Decis flow 2.5 , $0.058 \mathrm{mg} .1^{-1}$, essentially corresponds to $0.00145 \mathrm{mg} .1^{-1}$ deltamethrin. The values observed by us are in agreement with those reported by other authors who have determined the toxicity of deltamethrin for various species of fish. Haug and Hofman (1990) report the mean lethal toxicity for various fish species in laboratory conditions as varying between LC50 0.001 and $0.01 \mathrm{mg} . \mathrm{l}^{-1}$, Golow and Godzi (1994) state the value LC50 $0.0037 \mathrm{mg} . \mathrm{l}^{-1}$ for giebel carp and LC50 $0.008 \mathrm{mg} . \mathrm{l}^{-1}$ for Lepomis macrochirus. Srivastava et al. (1997) report LC50 $0.00186 \mathrm{mg} .1^{-1}$ for Heteropneustes fossilis, Gangolli et al. (1999) report the values of $96 \mathrm{hLC50}$ for carp, rainbow trout, cichlids and sunfish as varying between 0.0005 and $0.0018 \mathrm{mg} . \mathrm{l}^{-1}$.

The main haematological response of carp to the acute effect of the deltamethrin-based preparation at a $0.13 \mathrm{mg} . \mathrm{l}^{-1}$ concentration was a significant $(p<0.01)$ decrease in erythrocyte count, haematocrit, haemoglobin content and total protein content in blood plasma, compared to the control group. Rabindra-Nath and B anerjee (1996) report a decrease in total leukocyte count and neutrophil granulocyte count in Heteropneustes fossilis following poisoning with cypermethrin. Similar changes in the white blood picture are also reported by Sopinska and Guz (1998) in carp following acute poisoning with permethrin. After a prolonged poisoning of common carp with permethrin, Sopinska et al. (1995) observed increased neutrophile granulocyte count and monocyte count, decreased metabolic 
activity of neutrophil granulocytes and lysozyme in blood plasma. Campana et al. (1999) point out the genotoxic effect of lambda-cyhalothrin, revealed by an erythrocyte micronuclear test in Cheirodon interruptus interruptus.

\section{Vliv deltamethrinu na hematologické ukazatele kapra (Cyprinus carpio L.)}

Cílem práce bylo zhodnotit účinek deltamethrinu [(S)- a -cyano-3-fenoxybenzyl (1R,3R)3-(2,2-dibromvinyl)-2,2-dimethylcyklo-propankarboxylat] na kapra obecného (Cyprinus carpio L.). Účinek byl posuzován na základě výsledků testu akutní toxicity a na základě porovnání výsledků hematologického vyšetření kontrolní a pokusné skupiny vystavené působení pesticidního přípravku Decis flow 2.5 (účinná látka $25 \mathrm{~g} . \mathrm{l}^{-1}$ deltamethrinu). Test akutní toxicity byl proveden semistatickým způsobem po dobu 96 hod. na plůdku kapra. Hodnota $96 h L C 50$ přípravku Decis flow 2.5 byla $0,058 \mathrm{mg} \cdot \mathrm{l}^{-1}$. Vyšetření červeného a bílého krevního obrazu bylo provedeno u 15 kusů kontrolních $\mathrm{K}_{1-2}$ a u 28 kusů $\mathrm{K}_{1-2}$ po 96 hodinovém působení přípravku Decis flow $2.5 \mathrm{v}$ koncentraci $0,13 \mathrm{mg} . \mathrm{l}^{-1}$. U pokusné skupiny kaprů $\mathrm{K}_{1-2}$ byly zjištěny signifikantně nižší hodnoty $(p<0,01)$ počtu erytrocytů (RBC), obsahu hemoglobinu (Hb), hematokritu (PCV) a celkových bílkovin v krevnî plazmě (TP) ve srovnání s kontrolní skupinou. Hodnoty MCV, MCH a MCHC byly u pokusné a kontrolní skupiny srovnatelné. Rovněž hodnoty celkového počtu leukocytů a relativního a absolutního počtu lymfocytů, monocytů, neutrofilních granulocytů a jejich vývojových forem u kontrolní a pokusné skupiny byly srovnatelné. Pesticidní př́ipravek na bázi deltamethrinu Decis flow 2.5 byl zařazen mezi látky silně jedovaté pro ryby. Na základě změn červeného krevního obrazu a změn koncentrace celkových bílkovin v krevní plazmě po působení přípravku na bázi deltamethrinu lze usuzovat na možnost poruchy krvetvorby a proteosyntézy.

\section{Acknowledgements}

This research was supported by the Ministry of Education, Youth and Physical Training of the Czech Republic (MŠMT Project No. 162700004) and project FRVŠ MŠMT 360/2002.

\section{References}

BRAIDWOOD, JC, HART, JL 1998: Control of sea lice in fish. Grampian Pharmaceuticals Limited

BRADBURY, SP, COAST, JR 1989a: Comparative toxicology of the pyrethroid insecticides. Environ Cont Toxicol 108: $134-177$

BRADBURY, SP, COAST, JR 1989b: Toxicokinetics and toxicodynamics of pyrethroid insecticides in fish. Environ Toxicol Chem 8: 373-380

CAMPANA, MA, PANZERI, AM, MORENO, VJ, DULOUT, FN 1999: Genotoxic evaluation of the pyrethroid lambda cyhalothrin using the micronucleus test in erythrocytes of the fish Cheirodon interruprus interruptus. Mutation Research Genetic Toxicology and Environmental Mutagenesis 438: 155-161

GANGOLLI, ED et al. 1999: The dictionary of substances and their effects. Second Edition, Royal Society of Chemistry, Cambridge, Vol. 3: 71-75

GOLOW, AA, GODZI, TA 1994: Acute toxicity of deltamethrin and dieldrin to Oreochromis niloticus. Bull Environ Contam Toxicol 3: 351-354

HAUG, G, HOFMAN, H 1990: Chemistry of plant protection 4: Synthetic pyrethroid insecticides: Structure and properties. Springer-Verlag, Berlin, Heidelberg. Ex. The Extension Toxicology Network. PIPs. extoxnet@ace.orst.edu

HAYES, AW 1994: Principles and methods of toxicology. Raven Press, New York, 1468 p.

HILL, IR, HEIMBACH, F, LEEUWANGH, P, MATTHIESSEN, P 1994: Review of aquatic field tests with pyrethroid insecticides. Freshwater field tests for hazard assessment of chemicals, Lewis Publishers, Boca Raton, $561 \mathrm{p}$.

MARTINSEN, B, ALEXANDERSEN, S, FOSSUM, BH 2001: Deltamethrin, an effective treatment against the isopod sea lice Ceratothoa oestroides infecting farmed sea bass (Dicentrarchus labrax). In: Disease of fish and shellfish, Tenth International Conference, Trinity College, Dublin, Ireland, O-096

MAUD, SJ, HAMER, MJ, WARITON, JS 1998: Aquatic ecotoxicology of the pyrethroid insecticide lambdacyhalothrin: consideration for higher-tier aquatic risk assessment. Pestic Sci 54: 408-417

NEMCSOK, J, BALINT, T, FAZEKAS, J, KATAI, F, KISS, I, HIEU, LH, KUFCSAK, O, LANG, G, POLYHOS, 
C, SZABO, I, SZEGLETES, T 1999: The contribution of a pyrethroid insecticide to the massive eel (Anquilla anquilla ) devastation, in Lake Balaton, in 1995. Acta Biol Hung 50: 161-173

RABINDRA-NATH, BANERJEE, V 1996. Effects of pesticides methyl parathion and cypermethrin on the airbreathing fish Heteropneustes fossilis. Environ Ecol 14: 163-165

ROTH, M 2000: The availability and use of chemotherapeutic sea lice control products. Contr Zool 69:109-118

SEVATDAL, S, HORSBERG, TE 2001: Monitoring of sensitivity/resistance of norwegian salmon lice

(Lepeophtheirus salmonis K.) strains to pyrethroids (deltamethrin and cypermethrin) with bioassay. In : Disease of fish and shellfish, Tenth International Conference, Trinity College, Dublin, Ireland, P-161

SOPINSKA, A, GUZ, L 1998: Influence of permethrin on phagocytic activity of carp. Med Wet 54: 126-128

SOPINSKA, A, LUTNICKA, H, GUZ, L 1995: The influence of permethrin on the immune system of carp. Med Wet 51: 747-750

SRIVASTAVA, SK, JAISWAL, R, SRIVASTAVA, AK 1997: Lethal toxicity of deltamethrin (Decis) to a freshwater fish Heteropneustes fossilis. J Adv Zool 18: 23-26

SVOBODOVÁ, Z, PRAVDA, D, PALÁČKOVÁ, J 1991: Unified methods of haematological examination of fish. Research Institute of Fish Culture and Hydrobiology, Vodňany, 31 p.

TOOVEY, JPG, LYNDON, AR 2000: Effects of hydrogen peroxide, dichlorvos and cypermethrin on subsequent fecundity of sealice, Lepeophtheirus salmonis, under fish farm conditions. Bull Eur Ass Fish Pathol 20: 224-228 